\title{
Entangled Tropical Knowledges: Towards a Poetics of Knowledge and Place-Making in Nineteenth Century Voyaging Narratives
}

\author{
Michael Davis
}

Honorary Research Fellow, Sydney Environment Institute, The University of Sydney

\begin{abstract}
Footsteps mark the land as people walk through the north eastern Queensland tropics. Here, in the mid-1800s, botanical explorers from the survey ship HMS Rattlesnake scour their newly encountered environment for species that will be sent as specimens to the growing collections in London. Local Aboriginal people walk with them, perhaps as guides, possibly interpreters. The narratives for this voyage refer to some individual Aboriginal people who accompanied the Europeans as cotaiga, companion - a word from one of the Cape York Peninsula languages. Meetings and encounters between these voyagers and the local people take place around conversations and communications concerning local environmental knowledge. In this paper I look more closely at these 'knowledge encounters', to consider the complex poetics of entanglements between local Indigenous knowledges and Western modes of knowledge and representations of the local environment. Interrogating the voyaging narratives for their depictions of these encounters-in-place, my paper will meditate upon philosophies of movement, of walking and being in place, and of place making in the tropics. The paper will also ask questions about the role of historical representations of entangled tropical knowledge formations in present day concerns about climate and environmental change.
\end{abstract}

$\mathbf{F}$ ootsteps mark the land as people walk through the north eastern Queensland tropics. It is November 1847, and the British survey ship H.M.S. Rattlesnake has landed near Port Curtis, some 40 kilometres south of Rockhampton. Here, there was collecting to be done, for 'specimens of natural history'. The ships' naturalist, Scotsman John MacGillivray described a 'typical collecting expedition' in his Narrative, published in 1852:

In company with Mr. Huxley, I made an excursion of two days' duration, with the double view of seeing the country and adding to my collection. We started heavily laden with provisions, water, arms and ammunition, besides boxes, botanical paper and boards, and other collecting gear; and although taking it very easily, the fatigue of walking in a sultry day, with the thermometer at 90 [degrees] in the shade, afforded a sample of what we had afterwards so often to experience during our rambles in tropical Australia (MacGillivray, 1852, I, p. 55).

MacGillivray's phrase 'rambles in tropical Australia' suggests a sense of wandering, somewhat without a specific purpose. A ramble through the tropics conveys an impression of languidness, a leisurely, casual stroll, unburdened with immediate objectives. Yet how does this image sit with the notion of a focused, intentional activity, for securing specimens for the 
empire's scientific collections, that was the expedition's stated objective? If we consider the possibility that for MacGillivray and others on the expedition, the tropics was an unpleasant and difficult region at first, then the idea of 'rambling' through the humid, tangled bush seems unlikely. A purposeful walking is more plausible.

MacGillivray is walking though the bush in tropical Australia, intent on adding to his collection. At the same time, he also experiences the country, physically, but also in sensory ways. Taking anthropologist Tim Ingold's notion of 'wayfaring', we can imagine that, as MacGillivray walks though the hot countryside, he is alive to the experiences of what he observes, hears, smells, and feels around him. At the same time, he is absorbing information, not only by way of traversing the landscape, but also instrumentally, through his collecting. As Ingold describes it, through 'the embodied experience of his perambulatory movement', the wayfarer is 'becoming knowledgeable; he is 'inhabiting the earth' and coming to know it (Ingold, 2011, p. 148). Ingold explains: 'For the walker, movement is not ancillary to knowing - not merely a means of getting from point to point in order to collect the raw data of sensation for subsequent modelling in the mind. Rather, moving is knowing. The walker knows as he goes along (Ingold, 2015, p. 47).

We might surmise then that MacGillivray is 'walking into knowledge' as he is journeying on foot through the newly experienced tropics, finding, and classifying plants and animals, many of which he thought to be 'new to science'. But how does this knowledge connect to the particular places that MacGillivray traverses? Knowledge, embodied in the person, is, as we know from our understandings of Indigenous cosmologies, also powerfully embedded in landscape and place. If knowledge is developed in the walker, then it can come to be, in a sense, everywhere. So it is at the same time, everywhere, but also situated, localised in place. This notion that knowledge travels, and is also attached to specific places, is captured by English poet and essayist John Clare (1793-1864).

\section{John Clare 'Out of my Knowledge'}

Clare wrote in one of his autobiographical fragments:

Knowledge gives us a great number of lessons for nothing like Socrates she is not confined to Halls or colledges or forum(s) but like him accompanys us in our walks in the fields and attends on us at our homes ... in fact she is every where with us ready to instruct and assist our enquireys ... we have only to feel a desire to come at the means of her acquaintance and she is instantly ready to instruct us how to meet with the matter (Robinson \& Powell, 2004, p. 482).

But elsewhere, he describes a walk he took away from his beloved local fields:

... I had imagind that the worlds end was at the edge of the orison and that a days journey was able to find it ... so I went on with my heart full of hopes pleasures and discoverys expecting when I got to the brink of the world that I could look down like looking into a large pit and see into its secrets the same as I believd I could see heaven by looking into the water ... so I eagerly wanderd on and rambled among the furze the whole day till I got out of my knowledge when the very wild flowers and birds seemd to forget me and I imagind they were the inhabitants of new countrys...(Robinson \& Powell, 2002, p. 40). 
Here, Clare's concern at being 'out of his knowledge', conveys a sense of the localness of knowledge. If the walker strays beyond a place of situated knowledge, he is 'out of his knowledge'.

Henry David Thoreau, one of the great walkers and chronicler of woodlands also understood the relationships between knowledge, sensibility, and place. He wrote 'I have met with but one or two persons in the course of my life who understand the art of Walking, that is, of taking walks, ......- who had a genius, so to speak, for sauntering ....' (Thoreau, 1893, IX, p. 251). Like Clare, Thoreau envisaged the way that being in the woods - a familiar place restored, or brought about a connection to the inner being, when he claimed 'I think that I cannot preserve my health and spirits, unless I spend four hours a day at least, - and it is commonly more than that, - sauntering through the woods and over the hills and fields, absolutely free from all worldly engagements' (Thoreau, 1893, IX, p. 254). Thoreau ruminates on the predicament of walking into the woods, but not being in the woods, in that particular place and moment, in a sensory, or phenomenological sense: 'I am alarmed when it happens that I have walked a mile into the woods bodily, without getting there in spirit. In my afternoon walk I would fain forget all my morning occupations and my obligations to society. But it sometimes happens that I cannot easily shake off the village' He claimed of the alarming proposition that 'the thought of some work will run in my head and I am not where my body is, - I am out of my senses (Thoreau, 1893, IX, p. 258-259).

This association of walking with a particular mental state is also summed up by Rebecca Solnit in her book Wanderlust, where she states of walking that it is, 'ideally, a state in which the mind, the body, and the world are aligned, as though they were three characters finally in conversation together, three notes suddenly making a chord', She continues 'Walking allows us to be in our bodies and in the world without being made busy by them. It leaves us free to think without being wholly lost in our thoughts' (Solnit, 2000, p. 5). The physical act of walking is critical here, as Solnit writes:

The rhythm of walking generates a kind of rhythm of thinking, and the passage through a landscape echoes or stimulates the passage through a series of thoughts. This creates an odd consonance between internal and external passage, one that suggests that the mind is also a landscape of sorts and that walking is one way to traverse it (2000, p. 5-6).

Ingold and Vergunst also point to the knowledge formation established through walking, stating '...the movement of walking is itself a way of knowing' (2008, p. 5). But walking is not only the act of creating footprints on the ground, as a linear movement along, or the formation of, a path or track. It is also performing meaning, and inscribing. As Ingold and Vergunst suggest, footprints 'in their texture, their temporality and their literal embeddedness in a landscape of habitation ... should be likened to inscriptions, to lines traced in a surface rather than stamped upon it' (2008, p. 8).

To explore the connection between walking and knowledge further, I return to our intrepid Scots naturalist John MacGillivray as he explores the north Queensland tropics in search of natural history specimens. Often, MacGillivray is accompanied by local Aboriginal people. These peoples' deep knowledge of the country has proved to be important to the explorers' collecting and identifying the flora and fauna. We find MacGillivray remarking in a letter to one of his patrons on the way in which local Aboriginal knowledge has contributed to his finding of plants and animals. In May 1849 he wrote to John Gould, the British ornithologist 
who sponsored many naturalist collectors, describing a visit of some five months to Cape York Peninsula in May the previous year. MacGillivray wrote that 'we had as many as 200 natives (of various tribes) assembled at one time'. Although, initially at least, the explorers were wary of the local Aborigines, they frequently recorded in their narratives the role the local people had in the voyagers' project, as MacGillivray remarked 'They assisted in watering; came on board occasionally; and one or two used to accompany me in my otherwise solitary rambles in the bush, without any attempt at mischief'- ${ }^{1}$ Writing again to Gould in February 1850, MacGillivray described a second visit to Cape York in 1849, made while its companion vessel completed a survey of Torres Straits. Here, he found 'several species of birds, of the existence of which we were not before aware ...'. The naturalist claimed that ' - it was chiefly by our intimacy with the natives that we succeeded in getting so many new birds....'. MacGillivray had, on a previous visit to this region, secured some specimens of a local bat species, but some of these had decomposed. Again, we see local Aboriginal knowledge as critical to the naturalist's enterprise, as he wrote to Gould 'I may get another at Cape York, as it is well known to the natives, who, upon at least one occasion, directed my attention to its cry'.2

Taking these examples as indicative of much of the British natural history collecting project, the embedding of Indigenous environmental knowledge might be construed as a significant part of the production of an entangled colonial knowledge formation. Collaborative walking, journeying and wayfaring - British explorers accompanied by local Aboriginal people - is a vital part of this complex.

Aboriginal people often accompanied explorers, as guides and interpreters, but their agency is only relatively recently becoming an increasing focus of inquiry in histories of exploration and encounter. Aboriginal peoples' roles were multiple: trade and exchange were vital to the success of expeditions such as that by the Rattlesnake. And Aboriginal people were often instrumental in negotiating power and authority relations between different local groups and the intruders. But there was much more going on, and relationships with local Aboriginal people became increasingly complex as more time was spent at particular places. Local people came to be identified by name, and they assumed individual identities and personalities in the voyagers' texts. These local people, as a number of scholars have argued, acted as interlocutors, intermediaries, or 'go-betweens'. In the narratives of the Rattlesnake voyage, individual Aboriginal people were described as cotaiga - a word from a local Cape York Aboriginal language, was glossed as companion. Many meetings and encounters between these voyagers and the local people took place around conversations and communications concerning local environmental knowledge.

Midshipman and ship's clerk Charles Card too, in his diary of the voyage, recorded in early November 1849 his impressions of an encounter with Aboriginal knowledge. While at Evans Bay on the north east Cape York Peninsula, he wrote that he "took a stroll into the lagoon

\footnotetext{
${ }^{1}$ MacGillivray to Gould, HMS Rattlesnake at Sea - May $12^{\text {th }} 1849$; Moreton Bay - May $19^{\text {th }} 1849$, In Sauer, G.C. (Ed.). (1982). John Gould, the Bird Man: a Chronology and Bibliography, pp. 306-307. Melbourne; New York: Lansdowne Editions.

${ }^{2}$ MacGillivray to Gould, 29 [?] February 1850, From Jardine's 1850 Contributions to Ornithology 92 - [107], Gould authored this article entitled "A brief account of the researches in natural history of John MacGillivray, Esq. the naturalist attached to H. M. Surveying Ship the Rattlesnake ... ". Quotes from four letters were included in the Gould article, dated May 12, 1847, February 6, 1848, May 12 \& 19, 1849 and February 29, 1850. In Sauer, G.C. (Ed.). (1982). John Gould, the Bird Man: a Chronology and Bibliography, pp. 398-399. Melbourne; New York: Lansdowne Editions.
} 
accompanied by two or three natives and among them [one] who called himself 'Tchow' [?] and one who was a great chum of mine". Here, Tchow "got me some kind of red fruit with a large stone in the middle which he made signs for me to eat, which I did and found very good". The "old man", said Card, "was quite a botanist having a different name for every different kind of tree and seemed very proud of his knowledge". ${ }^{3}$ The young English ship's clerk here appeared to be enjoying meeting with these local people, as they "had a little fun throwing spears and afterwards bathed with a number of natives and, he wrote, they "then showed us the way they secured the turtle after the peg was in him ...". This was an area rich in potential food, as Card records that "old Tchow took me to plenty of green mountain parrots but I only shot one as they were very wild". 5

Through these 'knowledge encounters', Aboriginal and European collaborations over plants and animals provide a critical element in the formation of an entwined knowledge formation - comprised of both Indigenous and colonial/scientific.

Walking together through the tropics, for both explorers, and local Aboriginal people, also, I argue, was a way of making, or (re)-making place, though in significantly different ways for Aborigines and British. As the local Aboriginal people walk through their country and impart local environmental knowledge to the Europeans, they might also be performing and inscribing this country into their cultural registers - perhaps a different kind of 'walking into knowledge' - while at the same time enacting their roles as intermediaries. It can also be surmised that they are re-affirming their rights in the country.

For the British actors in these dramas of encounter, place-making was construed in very different terms. In the wider context, natural history surveying and collecting expeditions such as that of the Rattlesnake were part of the global imperial science project. The colonial expansion and settlement program sought new territories and resources. For the individual participants in these voyages, they occupied somewhat ambiguous positions. While their seaborne voyages brought them across the oceans, as cogs in the micro-states of empire that replicated the anxieties of class and status, here, in these far-flung coastal and island places at the fringes of empire, they were, in a sense, out of time and place. What this implied for MacGillivray is that, in walking through the north Queensland tropics and engaging with local Aboriginal people, he is establishing himself, perhaps re-making himself in a new, exotic and somewhat alien environment. He is compelled to fulfil various roles; acclimatise himself at a personal and psychological level to the new place and its peoples, while at the same time, pursuing the collecting project as one of many 'agents of empire'.

\section{Representations of Environment}

Attending to the textual depictions in voyaging narratives of the multiple ways in which British voyagers and local Aboriginal people collaborated in walking through the tropics, enables some insights to be gleaned into modalities around representative practices concerning environmental knowledge. At the same time, close scrutiny of the records by those such as MacGillivray also enable a vision to be constructed of a wider historicalenvironmental discourse, one that has potential implications for understanding environmental

\footnotetext{
${ }^{3}$ Charles Card, Diary, Thursday 1 November 1849, 2770 Charles James Card Diaries, Oxley Library, Brisbane.

${ }^{4}$ Charles Card, Diary, Thursday 1 November 1849, Oxley Library, Brisbane.

${ }^{5}$ Charles Card, Diary, Thursday 3 November 1849, Oxley Library, Brisbane.
} 
change. I draw on further examples from MacGillivray's narrative to illustrate some of these ideas.

Aberdeen born John MacGillvray was part of an extensive global network of natural history collectors throughout the colonial world, centred on Kew Gardens and the British Museum. ${ }^{6}$ The Rattlesnake voyage was not his first, as he had been a private collector for the Earl of Derby on HMS Fly, which surveyed the tropical north Queensland region during 1842 to 1846. Typically for these scientific surveying voyages, the Rattlesnake aimed to fulfil the grand imperial design, to ascertain the suitability of the region for European settlement and pastoral expansion, to describe, collect, and to domesticate both nature, and native peoples. But close scrutiny of MacGillivray's Narrative and other voyaging texts, also offers a glimpse of a historical environment and climate, that might be used as a basis for comparing changes over time - and therefore potentially of use in evaluating and addressing current and future trends in climate change. This is especially critical for Cape York Peninsula, where fragile and eroding coastal environs threaten Indigenous peoples' lives.

Port Curtis is described by MacGillivray as

... a space of about ten miles in length, ... enclosed between Facing Island on the east, or to seaward, Curtis Island on the north, and the shores of the main land on the western side, leaving to the southward a wide entrance partially blocked up by shoals ... (MacGillivray, 1852, I (?), p. 53-54).

The absence or presence of water is a constant and enduring concern:

We landed almost daily upon Facing Island, which was traversed in every direction, but nowhere could we find a practicable watering place for the ship .

The naturalist conveys a sense of sameness and monotonous of the landscape; and water is an enduring image, variously in abundance, or scarcity:

Its aspect is various; the shores, as well as those of the adjacent main land, are often muddy, and covered with mangroves, fringing creeks, and occupying swamps more or less extensive, while the rest of the country is either covered with the usual monotonous gum-trees, or, as over a large portion of the sea face, covered with coarse sedgy grass and small bushes, on sandy ground, which rises into a series of low sand hills extending along the coast. During winter there must be much water, judging from several nearly dried up lagoons and swamps, and some empty water-courses (MacGillivray, 1852, I (?), p. 54).

Alert to the seasonal variations of water, MacGillivray remarks:

We found no fresh water during our walk; of two wells which had been dug by the settlers, though stiff clay, one was dry, and the other contained a puddle of brackish

\footnotetext{
${ }^{6}$ Although these were the two major institutions at this period for developing natural history collections, there were tensions between them, as MacGillivray considered Hooker's Kew Herbarium to be 'accessible to every botanist properly recommended, and has been and will be more conducive to the promotion of botanical science than that of the British Museum', letter to Sir William Hooker, written at Camden Town, 14 February 1852, Vol. 32, Folio 280 in Directors' General Correspondence, Kew Gardens Archives, London.
} 
water, not fit to drink. We met with few birds, but saw many tracks of emus and kangaroos (MacGillivray, 1852, I (?), p. 57).

We now find images of plentiful water, as on $20^{\text {th }}$ May, MacGillivray again heads off on a 'solitary ramble'. He is searching for 'a kind of rock wallaby, or small kangaroo, peculiar to this place, and which I failed on this occasion (as during two previous visits) to procure'. He describes the scene:

I walked as far as the place where the Fly [survey ship travelling through these parts earlier] had watered some years previously. The large rocky basin which we had found dry in December last, when the whole plan of our first northern cruize [sic] had to be altered, in consequence of this unexpected result, was now nearly full. The aspect of the country had been considerably changed by the late abundant fall of rain, and the vegetation everywhere looked quite green.

....In all probability this is the embouchure of a considerable fresh water stream, but the shallowness of the head of the bay and the usual bar off the mouth of the supposed river, determined Captain Stanley to return to the ship, as the time which would otherwise have been spent in exploring an useless creek might be devoted to some better purpose (MacGillivray, 1852, I (?), p. 99-100).

These samples from the naturalist's journal enable a historical picture to be formed of a viable and sustainable Indigenous resource economic system and environment.

\section{A Varied Tropical Imaginary}

Textual readings of narratives of the Rattlesnake depict varied environmental representations of the tropics. Water and its lack is a consistent trope in MacGillivray's text, and this is juxtaposed with images of dryness and barrenness. These images of environments, ecologies, and of botany and natural history populate the voyaging narratives, and are an important component of the production of a particular colonial knowledge formation.

Geographer Felix Driver discusses the 'disciplining of geographical knowledge', which concerns 'the production and circulation of authoritative knowledge about the tropical world during the eighteenth and nineteenth centuries' (Driver, 2004, p. 1). In Driver's thesis, the tropics is as much as state of mind, as it is an actual place or region. He states 'we might think of ideas about tropical difference as part of a wider discourse of Orientalism which works to define and delimit the essential difference between East and West. This is a discourse of 'tropicality', which forms a significant influence on the European imaginary in colonial exploration and voyaging. Driver also reminds us of the Greek origins of the word "tropics" - meaning 'a turning, which refers both to the rotations of the spheres and the notion of limits, here both natural and moral. The inter-tropical zone has frequently been imagined, as it was in antiquity, as a realm of otherness, beyond the habitable human realm' (Driver, 2004, p. 2). We can extend this notion to perspectives on colonial images of north east Queensland tropics. The imagery in MacGillivray's text of dryness, barrenness and monotony form only a part of the repertoire of constructions of the tropics. These particular images partly contribute to a negative discourse on the tropics that depict these regions in terms of hostility and alienation, as places apart, and unfit for white people. Ideas abound on associations between the tropics, and human degeneration, lassitude and disease. Historian Warwick Anderson has taken up these ideas, writing 
As the south-eastern parts of Australia became a domesticated British territory, the northern tropics continued to challenge even the most hardy of white sojourners. By the end of the nineteenth century, the temperate zone of the continent was exonerated as a cause of disease or degeneration among transplanted Britons, but above Capricorn heat and moisture still threatened to sap the vital forces of working white men and their dependent wives and children. Increasingly, the Australian tropics were marked off as a separate, racially dubious territory, in contrast to the more cultivated, picturesque and innocuous southeastern crescent. In medical texts, geographical reports, and popular literature, 'tropical' was positioned against 'temperate'; 'wilderness' against 'civilisation'; 'promiscuity' against 'restraint'; and in a racial summation of these dichotomies, 'coloured' contrasted with 'white'. The sense of tropical difference that emerged and filled out during the nineteenth century came to represent an impediment to a purely white Australia (Anderson, 2002, p. 73).

Some of these ideas pervade north east Queensland's tropics which, in Anderson's words, is littered with a history of 'failed and forsaken settlements' (Anderson, 2002, p. 76). One such place was Port Essington, established in 1838. Thomas Henry Huxley, Assistant Surgeon on the Rattlesnake, who was to make his name as a leading figure in Victorian science, painted a dismal picture of Port Essington:

As for the place itself it deserves all the abuse that has ever been heaped upon it. It is fit for neither man nor beast. Day and night there is the same fearful damp depressing heat, producing and unconquerable languor and rendering the unhappy resident a prey to ennui and cold brandy-and-water (Anderson, 2002, p. 77).

Another, very brief settlement was a convict station at Port Curtis in 1847, abandoned after only a couple of months. MacGillivray described this:

On another occasion Mr. Huxley and myself landed at the site of the settlement of Gladstone, and were picked up in the evening by Capt. Stanley in one of the surveying boats, on his return to the ship. It is difficult to conceive of a more dreary spot, and yet I saw no more eligible place for a settlement on the shores of the harbour. A few piles of bricks, the sites of the tents, some posts, indicating the remains of a provisional "Government-house," wheel-ruts in the hardened clay, the stumps of felled trees, together with a goodly store of empty bottles strewed about everywhere, remained as characteristic of the first stage of Australian colonization. Within 200 yards of the township we came upon a great expanse of several hundred acres of bare mud, glistening with crystals of salt, bordered on one side by a deep muddy creek, and separated from the shore by thickets of mangroves. The country for several miles around is barren in the extreme, consisting for the most part of undulating, stony, forest land. ... I have heard, however, that there is much good pastoral country at the back (MacGillivray, 1852, I, p. 56-57).

\section{A Summing up of sorts ...}

Walking through the tropics then, becomes a journey into knowledge, a site or locus for production of entangled European and Aboriginal knowledges. Walking as movement, as a kind of wayfaring, is also inscribed textually, as it is inscribed through markings on the landscape. As texted movement, encapsulated through nineteenth century voyager narratives, 
landscape, environment, and diverse knowledge formations indicate representative practices informed by discourses of the tropics at once enervating, torpid and potentially degenerative. Alongside, are also images of abundance, of fertility, and of a potentially useful country for settlement and development. Complicating these diverse discursive formations are images of collaborative engagement between Aborigines and British, and of mutually involved botanical and natural history knowledge-making and inquiry.

\section{Works Cited}

Anderson, W. (2002). The Cultivation of Whiteness, Science, Health, and Racial Destiny in Australia, Carlton, Victoria: Melbourne University Press.

Driver, F. (2004). Imagining the Tropics: Views and Visions of the Tropical World. Singapore Journal of Tropical Geography, 25(1), 1-17.

Ingold, T. (2011). Being Alive: Essays on Movement, Knowledge and Description. London and New York: Routledge.

Ingold, T. (2015). The Life of Lines. London and New York: Routledge.

Ingold, T., \& Vergunst, J.L., (2008), Introduction, In T. Ingold and J. L. Vergunst (Eds.), Ways of Walking: Ethnography and Practice on Foot, pp. 1-19. Aldershot: Ashgate.

MacGillivray, J. (1852). Narrative of the Voyage of H. M. S. Rattlesnake. London: T. \& W. Boone, 2 volumes.

Robinson, E., \& Powell, D. (Eds.). (2004). John Clare, Major Works. Oxford: OUP.

Robinson, E., \& Powell, D. (Eds.) (2002). John Clare by Himself. Oxford: OUP.

Sauer, G.C (Ed.). (1982). John Gould, the Bird Man: a Chronology and Bibliography, Melbourne; New York: Lansdowne Editions.

Solnit, R. (2002). Wanderlust, A History of Walking. New York, NY: Viking.

Thoreau, H.D. (1893). 'Walking', in The Writings of Henry David Thoreau, Vol IX, Excursions. 